This is the version of the article accepted for publication in Review of Keynesian Economics, Vol. 5 (4), 576-585 published by Edward Elgar: http://dx.doi.org/10.4337/roke.2017.04.07

Accepted version downloaded from SOAS Research Online: http://eprints.soas.ac.uk/24792/

\title{
FROM MARX TO THE KEYNESIAN REVOLUTION: THE KEY ROLE OF
}

\section{FINANCE}

Jan Toporowski, SOAS University of London

\begin{abstract}
The Companies Acts of the 1860s initiated a major structural transformation in capitalism. This was noted, but not developed into a theory of the capitalist economy, by Marx. That development subsequently came in the work of Veblen, Hilferding and his critics Lederer and (implicitly) Kalecki, Keynes, Steindl and Minsky. The paper argues that the Great Schism in economic theory is not between Keynes and 'the Classics', as argued by Keynes; or Keynes and the neo-classical synthesis, as contended by Joan Robinson and Richard Kahn; nor even between monetary production and barter exchange, as maintained by Post-Keynesian writers; still less between political economists and apologetic theorists, as argued by Marxists. The key distinction in economic theory is between those who recognise the central role of longterm finance in the capitalist economy, and those theorists for whom finance is merely 'savings' or another form of credit.
\end{abstract}

Keywords: Post-Keynesianism, Marxism, money, finance

JEL classification: B15, B26, E12, E44 
This is the version of the article accepted for publication in Review of Keynesian Economics, Vol. 5 (4), 576-585 published by Edward Elgar: http://dx.doi.org/10.4337/roke.2017.04.07

Accepted version downloaded from SOAS Research Online: http://eprints.soas.ac.uk/24792/

\section{Introduction: Long-term Finance and the Critique of Political Economy}

This paper is intended not so much to provide new arguments, as to reconfigure the history of economic thought since the nineteenth century. This obviously entails some reference to the key authors of the time. However, in a synthetic work of this kind, covering a century and a half of discussion and disagreement, it is not possible to do more than generalise about one aspect of those discussions and controversies, namely the extent to which they recognised the structural shift in capitalism that occurred with the generalised availability, from the later decades of the nineteenth century, of long term finance. The section that follows shows how this new kind of finance stands between Marx and twentieth-century political economy, and how it forms the common thread in the work of Veblen, Hilferding, Keynes, Kalecki, Steindl and Minsky. A second section argues that, outside the discussions formed by these theorists, economics has tended to reduce finance to 'savings' or a form of credit that does not differentiate the key role that long-term finance has in the modern capitalist economy. The superiority of Post-Keynesian theory, broadly understood as taking in the theories of the above authors, lies in its recognition of the significance of long-term finance for capitalism, rather than in the 'realism' of any Post-Keynesian doctrine. Concepts of uncertainty, expectations, aggregate demand may be found in various schools of thought (see below). However, such concepts are usually allied to analysis that muddles finance with credit and savings. Only in the writings of Veblen, Hilferding, Keynes, Kalecki, Steindl and Minsky, is long-term finance distinguished from mere bank credit, or savings. This leads to a short conclusion reflecting on the directions in which economic theory is going in its consideration of finance. 
This is the version of the article accepted for publication in Review of Keynesian Economics, Vol. 5 (4), 576-585 published by Edward Elgar: http://dx.doi.org/10.4337/roke.2017.04.07

Accepted version downloaded from SOAS Research Online: http://eprints.soas.ac.uk/24792/

As is well-known Marx's political economy is based on a theory of value showing how value is created. Volume II of Capital was supposed to show how value is realised. The volume is the sub-titled The Process of the Circulation of Capital. Capital, as Marx described it, is the capitalists' expenditure on productive resources (labour, equipment and natural resources). The process of the circulation of capital is therefore what we now call the circular flow of income which represents the income flows that Marx described in the schemes of reproduction laid out in this volume. However, he was not satisfied with the draft he had written and intended to revise it. In particular, he showed in the volume a scheme of simple reproduction (reproduction without any increase in production, or of the capital stock), but he did not complete the exposition of expanded reproduction (Marx 1974a, chapters XX and XXI). The question of the conditions for realisation was to be taken up by Rosa Luxemburg in her Accumulation of Capital. In his book on Luxemburg's theory, Tadeusz Kowalik shows that Kalecki's theory of the business cycle is in effect the solution to the problem of value realisation that eluded Marx and Luxemburg (Kowalik 2014, Appendix 1)

The second and third volumes of Capital were written in the mid-1860s (Marx 1974b, p. 3). Since that time, a radical change occurred in the functioning of the capitalist economy, in the form of the emergence and proliferation of markets for long-term debt and shares in capitalist enterprises. Legislation from the 1860s onwards eased the establishment of joint stock companies in the advanced capitalist countries. Prior to this legislation, such companies had existed, but were largely restricted to trading companies, or infrastructure construction (railways, canals) rather than manufacturing. The companies legislation transformed capitalism from its 'classic' form in the mid-nineteenth century, in which capitalist enterprises were owned and controlled by individual capitalists and their more or less active partners, into its modern, twentieth-century form dominated by large joint-stock companies 
This is the version of the article accepted for publication in Review of Keynesian Economics, Vol. 5 (4), 576-585 published by Edward Elgar: http://dx.doi.org/10.4337/roke.2017.04.07

Accepted version downloaded from SOAS Research Online: http://eprints.soas.ac.uk/24792/

or corporations (Kindleberger 1993, chapter 11). Engels tried to incorporate this shift into Marx's Capital with a short chapter in the Stock Market that he added to Volume III of Capital (Engels ‘Supplement to Capital Volume Three', Marx 1974b). But this did not go beyond deprecating the speculation in that market, in terms that are common currency in modern, superficial critiques of finance.

The change in capitalist financing had two consequences of fundamental importance for the stability of capitalism. In the first place, large capitalist enterprises with access to capital (long-term debt and equity) markets were able to 'fund' their long-term industrial assets with bonds, or equity. This reduced their vulnerability to credit shortages. Before this change in financing, the 'classic' capitalist enterprise was typically financed with the owner's capital. As the mechanisation of production proceeded, there was an incessant need for additional capital usually met by short-term bank borrowing that had to be rolled over during the lifetime of the productive capital equipment that it was financing (see Dobb 1967, pp. 26-30; Niebyl 1946, chapter 3; Kindleberger 1993, pp. 94-96). If banks became reluctant to lend, the capitalist entrepreneur (Marx's 'functioning' capitalist) would be unable to roll over maturing debt and, faced with a squeeze on his liquidity, his company could fail. This is the financial crisis that is typical of 'classic' capitalism. It was described in the two texts that formed the basis of the theory of financial crisis both mainstream economics, and radical political economy, Tugan-Baranovsky's study of English banking crises, which influenced Dennis Robertson, Ralph Hawtrey, as well as John Maynard Keynes, and Henry Hyndman's Commercial Crises of the Nineteenth Century (Tugan-Baranovsky 1923, Hyndman 1932).

This banking crisis of 'classic capitalism', due to the short-term financing of longer-term capital equipment, is now the standard financial crisis theory of mainstream economics and 
This is the version of the article accepted for publication in Review of Keynesian Economics, Vol. 5 (4), 576-585 published by Edward Elgar: http://dx.doi.org/10.4337/roke.2017.04.07

Accepted version downloaded from SOAS Research Online: http://eprints.soas.ac.uk/24792/

radical political economics: a combination of bank illiquidity, due to maturity transformation, and credit 'crunch' as lending facilities are withdrawn due to that illiquidity. In his 1932 preface to the second edition of Hyndman's Commercial Crises, J.A. Hobson attributed the characteristics of nineteenth century crises to those of the twentieth century, with implicit underconsumptionist implications:

'... The interest of modern readers will be attracted by the common character of the nine crises of last century, and by the flood of light they throw upon the present troubles of the world. Even in the slump which followed the Napoleonic war the germ of all the later slumps was plainly discernable, the glut of commodities unsaleable by reason of the fall of prices, the stoppage of production throughout the industrial system, and the lingering waste of unemployment. In each succeeding crisis, though financial troubles figured as the immediate cause of collapse, the same paradox which confronts the world to-day was plainly visible, an acceleration of the power of production unaccompanied by a corresponding growth of purchasing and consuming power.' (Hyndman 1932, p. vii).

In is also worthy of note that in his book Hyndman did not mention the Barings crisis of 1893, a crisis that originated in the bond market and spread through the stock markets of Europe, Australia and the Americas. Those authors that did write about it have treated it like a bank 'run', rather than as a crisis of corporate finance (Hawtrey 1934, p. 364, Kindleberger 1993, pp. 275-277). But the change in capitalist financing did affect the organisational forms and structure of capitalist enterprise, the course of financial crisis, and capitalist dynamics in general. The emergence of long-term debt markets allowed the capitalist entrepreneur to refinance his short-term bank borrowing with long-term bonds. This virtually eliminated the vulnerability of the capitalist to a bank credit squeeze (cf. Hilferding 1981, pp. 87-88). At the 
This is the version of the article accepted for publication in Review of Keynesian Economics, Vol. 5 (4), 576-585 published by Edward Elgar: http://dx.doi.org/10.4337/roke.2017.04.07

Accepted version downloaded from SOAS Research Online: http://eprints.soas.ac.uk/24792/

same time, the capitalist entrepreneur had to ensure that his company now had sufficient liquid reserves to make interest and dividend payments on long-term debts, or equity, and then to make sure that the holders of the bonds or shares were not embarrassed by the drying up of liquidity in the markets for bonds or shares: such a drying up makes it difficult to sell a bond or share for a good price and condemns its owner to holding it until prices improve, with only a cash flow in the form of interest or dividends. Hence companies are obliged to hold excess capital that is turned over in restructuring their financing.

In the financial markets, a process of financial innovation took place creating the institutions and markets that provide liquidity for the long-term securities: a whole range of new banking and financial institutions now finance holdings of long-term securities with short-term borrowing. Early on, economists such as Withers and Hobson noted the shift in the basis of credit from commodity production and exchange to long-term securities (Withers 1917, Hobson 1924, chapter 5). Such 'layering' of credit (lending or borrowing in order to buy longer-term securities) then constitutes the proliferation of debt that is nowadays referred to as 'financialisation' (because debt stocks rise faster than real economic activity) but is really a way in which the financial system keeps the market for long-term securities liquid. Perhaps the most commonly-cited model of credit cycles, that of Kiyotaki and Moore has cycles driven by fluctuations driven by cyclical changes the 'net worth' of agents. However, their access to credit is determined by their ability of post real, i.e., productive, assets as collateral for loans, rather than the much more common (because there is more of them) use of financial assets as security for loans (Kiyotaki and Moore 1997).

The second major change attendant upon the expansion of long-term finance was the rise of monopoly capital. Companies could now expand far more expeditiously by buying their 
This is the version of the article accepted for publication in Review of Keynesian Economics, Vol. 5 (4), 576-585 published by Edward Elgar: http://dx.doi.org/10.4337/roke.2017.04.07

Accepted version downloaded from SOAS Research Online: http://eprints.soas.ac.uk/24792/

competitors' long-term debts or shares, rather than entering into the precarious business of competing their business rivals out of business. The corporate form of capitalism that emerged brought with it a change in the structure and dynamics of capitalism. The section that follows considers some of the theorists who recognised the fundamental character of this change and analysed its consequences.

\section{Taking Finance Seriously in the Twentieth Century}

The trusts and monopolies that dominated capitalism by the end of the nineteenth century were the creation of the capital markets, rather than, as Alfred Marshall believed, the results of either 'natural' monopolies or increasing returns to scale. For Rudolf Hilferding, the link with the capital markets forms the essence of monopoly capital. In his Finance Capital Hilferding first put forward an explanation of the new capitalist instability, caused by the interplay between monopoly and competitive segments in the capitalist economy. There are two elements in this new instability. First of all, because of their domination of markets, suppliers and credit, large corporations are able to secure a disproportionate share of profits, by comparison with smaller competitive firms. Secondly, the banking system 'substitutes its own credit for commercial credit... This puts the banks of issue in a position to meet the increased demands upon them in a crisis' (Hilferding 1981, chapter 20, p. 290-1). The old instability due to a run on bank credit is in effect replaced by instability due to the concentration of investment or capital accumulation in large corporations.

In Hilferding's view, this concentration had the potential to stabilise the cartelised sector by 'divert(ing) the main burden of a crisis to the non-cartelised industries' (ibid. p. 298). This potential for stabilisation was argued over by various Austro-Marxists, notably Emil Lederer 
This is the version of the article accepted for publication in Review of Keynesian Economics, Vol. 5 (4), 576-585 published by Edward Elgar: http://dx.doi.org/10.4337/roke.2017.04.07

Accepted version downloaded from SOAS Research Online: http://eprints.soas.ac.uk/24792/

(Lederer 1925). It terms very similar to those shortly to be used by Kalecki, Lederer argued that monopoly or finance would not stabilise capitalism, because corporations would tend to over-invest in a boom, while prices of consumer goods would tend not to fall in a recession, as wages fell. This insight that was systematically investigated by Michał Kalecki, who thought that he was addressing the Rosa Luxemburg's and Mikhail Tugan-Baranovsky's respective explanations of the conditions under which value is realised in the capitalist economy, but was really engaged in a critique of Hilferding's finance capital (Kalecki 1967, and 1932) $)^{1}$

In the second half of the twentieth century, the analysis of monopoly capital came to be associated with Paul Sweezy (see in particular Magdoff and Sweezy 1987). By then Hilferding was known largely for his integration of commercial banking with business enterprise rather than for his seminal insights into monopoly capital as the condition for the modern business cycle (cf. Howard and King 1989 pp. 94-103).

The question of the credit innovations that provided liquidity for the markets in long-term securities was addressed in the first half of the twentieth century in the work of Thorstein Veblen. He was the first theorist to explain the mechanics of the new financial crisis, precipitated by the breakdown of a stock market boom (Veblen 1904 chapter VII). This analysis influenced John Maynard Keynes. Numerous distinctive elements of Keynes's ideas emerge from his considerations of the consequences of long-term finance: his differentiation between the industrial and financial circulation of money, in the Treatise on Money; perhaps his most original monetary concept of the speculative demand for money; and his critique of

\footnotetext{
${ }^{1}$ The Polish Marxist Ludwik Krzywicki (1859-1941), who supported Kalecki's work, had earlier written on monopoly capital as a result of a visit in the 1880s to the United States, where Krzywicki witnessed at first hand the operations of American trusts: see Kowalik 1959, chapter III.
} 
This is the version of the article accepted for publication in Review of Keynesian Economics, Vol. 5 (4), 576-585 published by Edward Elgar: http://dx.doi.org/10.4337/roke.2017.04.07

Accepted version downloaded from SOAS Research Online: http://eprints.soas.ac.uk/24792/

the way in which the capital market functions arising out of the dependence of the capital market on expectations of future (and therefore uncertain) capital gains and income (Lawlor 1994; Keynes 1930 Volume 1, chapter 15; Keynes 1936 chapters 12 and 13).

Central to his considerations was the emphasis that Keynes placed on the differences between the short-term rate of interest, that is controlled, more or less, by the central bank, and the long-term rate of interest that is determined in the bond market. That long-term rate is important not only for the speculative demand for money, that is the demand for money from holders of financial portfolios who will postpone buying bonds (and therefore hold more money) if they expect that long-term rate of interest to rise. It is the long-term rate, rather than the short-term rate of interest, that, along with the 'state of long-term expectations' determines the level of investment. This is for the obvious reason that long-term bonds are the financial opportunity cost of a fixed capital investment and, whether financed from reserves or bank borrowing, the financing of fixed capital is stabilised by 'funding' or issuing long-term securities as the balance sheet counterpart of the fixed investment, and using the proceeds of the issue to replace reserves or repay short-term bank borrowing (Keynes 1936, pp. 202-204, Keynes 1930, Volume 2, chapter 27. See also Toporowski 2005, pp. 83-85).

These theoretical innovations by Keynes may be forced into a non-financial theory of capitalism only at the cost of losing their significance. Financial circulation, the speculative demand for money and trading against the future value of securities only really make sense in a capitalist economy with long-term finance. But that finance cannot be abstracted from production and investment and confined to portfolio choices, as it was in the neo-classical synthesis of Hicks and Tobin. 
This is the version of the article accepted for publication in Review of Keynesian Economics, Vol. 5 (4), 576-585 published by Edward Elgar: http://dx.doi.org/10.4337/roke.2017.04.07

Accepted version downloaded from SOAS Research Online: http://eprints.soas.ac.uk/24792/

In the second half of the twentieth century this financial approach to economic theory was taken up by Kalecki's associate Josef Steindl (Steindl 1952). Steindl in particular picked up the hint that appears in Hilferding's Finance Capital that the modern business cycle is the result of shifts in profits between the corporate sector that monopolises the capital market (the true meaning of 'monopoly capital') and the sector of small and medium-sized businesses that accounts for the bulk of private sector employment in capitalist countries (Steindl 1945). A parallel path, was followed by Hyman Minsky, by-passing medium and smaller firms but covering similar themes of credit cycles, drawn from the work of Keynes and Schumpeter. In his extensive consideration of Keynesian economics in 1975, Minsky stated that '.. within a capitalist economy, Keynes observed, "It is to an important extent, the 'financial' facilities that regulate the pace of new investment"; and it is the pace of investment that determines income and employment.' (Minsky 1975; the Keynes quotation is from 'Alternative Theories of the Rate of Interest' 1937). In his Stabilizing an Unstable Economy Minsky demonstrated the need for capitalist firms to maintain a certain level of investment expenditure in order to realise profits and make payments on their debts (Minsky 1986 chapter 8).

\section{Putting Finance in Its Black Box}

Outside the discussions of the theorists summarised in the previous section, economic theory has largely failed to comprehend the shift that had occurred as a result of the emergence of long-term finance. This incomprehension has been largely the result of two theoretical abstractions that may be found in the literature, the reduction of finance to credit in general, and the reduction of credit to saving or savings. The other way of abstracting finance from the analysis is the reduction of finance to merely a more specific form of credit or debt. 
This is the version of the article accepted for publication in Review of Keynesian Economics, Vol. 5 (4), 576-585 published by Edward Elgar: http://dx.doi.org/10.4337/roke.2017.04.07

Accepted version downloaded from SOAS Research Online: http://eprints.soas.ac.uk/24792/

This reduction of credit to saving is most apparent in the neo-classical literature, where the basis of economic activity is the exchange of 'real' resources, which finance merely passively facilitates. Hayek's doctrine of 'forced saving' is particularly relevant here as an attempt to show how credit becomes saving through a market process of price adjustment following a credit expansion (Hayek 1932). Keynes’s rival for the monetary estate of Alfred Marshall, Dennis Robertson, considered the equivalence between savings and credit to be one of the fundamental propositions of monetary economics (Robertson 1940, pp. 42-46). After the General Theory the 'credit-as-saving' view was rehabilitated in the neo-classical synthesis, where 'real' saving is brought into equilibrium with 'real' investment by the 'real' rate of interest, and a 'real' (i.e., credit-free, because investment is financed elsewhere from 'saving') money supply is also brought into equilibrium by that same 'real' rate of interest. Finance and credit was then dismissed most conclusively and, since the 2007 financial crisis perhaps most notoriously, in New Classical macroeconomics. Here credit and finance is assumed away and the 'real' rate of interest is merely the rate at which future 'real' incomes and expenditures are discounted to present values and resources set aside for consumption in retirement (the standard reference here is Woodford 2003).

The inadequacies of this reduction of credit to saving have become obvious in recent years, although the reduction remains a staple of development economics (the 'savings' gap literature) and international monetary theory in the Mundell-Flemming approach and numerous efforts to attribute international debt problems to trade imbalances (a critique of the latter is given by Borio and Disyatat 2015, and a more Post-Keynesian critique may be found in Chick 1983, chapter 9). The second abstraction, treating finance as merely another form of 
This is the version of the article accepted for publication in Review of Keynesian Economics, Vol. 5 (4), 576-585 published by Edward Elgar: http://dx.doi.org/10.4337/roke.2017.04.07

Accepted version downloaded from SOAS Research Online: http://eprints.soas.ac.uk/24792/

credit, allows at least for some analysis of banking and recognizes the monetary character of the rate of interest ${ }^{2}$.

The reduction of finance to credit is most clearly visible in 'theories' of financial crises that view them as essentially banking crises, due to such standard banking phenomena as speculation and maturity transformation (the standard model is Diamond and Dybvig). The author of the standard Manias, Panics and Crashes ought to have known better than to force financial crises from the seventeenth century to the twentieth century into the same mould (Kindleberger 1989). But he set a precedent for attributing common economic properties to credit and finance that continues today, most notoriously perhaps in the study of Reinhart and Rogoff that combines in one analysis the financial crises of eight centuries (Reinhart and Rogoff 2008). Underlying such approaches are usually attempts to ground economic events in the psychological characteristics of economic 'agents' or 'decision-makers'. With the widespread acceptance since the 1970s of 'micro-foundations' as a necessary methodological principle, the capitalist firm and its financing disappear from the mainstream narrative, replaced by exchange of surplus commodities between households, so that production and exchange are the results of household decisions. Finance is transformed into household decisions on savings portfolios, and corporate finance has been reduced to the choice of financing for household-based firms, and their 'information' and principal-agent problems, as if a century and half of financial development and innovation had simply not happened (see Shabani and Toporowski 2015).

\footnotetext{
2 ،... it is customary to say "the nominal rate of interest" but in the real world the rate of interest can only be nominal' Chick, op. cit. p. 229 ..
} 
This is the version of the article accepted for publication in Review of Keynesian Economics, Vol. 5 (4), 576-585 published by Edward Elgar: http://dx.doi.org/10.4337/roke.2017.04.07

Accepted version downloaded from SOAS Research Online: http://eprints.soas.ac.uk/24792/

In the twentieth century, Marxists, with rare exceptions (e.g., the later Sweezy in Sweezy and Magdoff 1987, Halevi 1992 and Bellofiore 2014), embarked on a journey back from Marx to Ricardian Socialism, to labour value as their price theory and underconsumption as the source of under-employment and poverty (Toporowski 2016). In the latter decades of the twentieth century, Post-Keynesians chose to settle in the foothills of the yield curve. Disputes over economic policy and the evident under-theorisation of money in the new monetarist macroeconomics inspired a concentration on principles of monetary endogeneity and uncertainty. This is most obvious in the work of the American Post-Keynesian Paul Davidson, with other Post-Keynesians grafting onto those principle components other elements, according to taste and research interest (Davidson 1978). Nevertheless, Post-Keynesianism, remains faithful to its original inspiration in being perhaps the only modern school of thought in economics that has taken finance seriously. But, rather than starting from the capitalist firm, recent Post-Keynesian analysis proceeds in general using the sectoral balances in the flow of funds analyses, into which fiscal policy (the original 'Keynesian' policy) may be fitted conveniently as a balance between the private sector net accumulation of assets (Saving minus Investment) and the trade balance (e.g., Palley 2010). The strength of the PostKeynesian approach, apart from its integration of finance into its monetary analysis through the speculative demand for money, lies in its theory of aggregate demand laying down the conditions under which value is realised. However, that theory is not integrated with any theory of value or production and the theory of distribution is usually treated as an optional supplement to the theory of aggregate output and employment. Post-Keynesian analyses do not offer any theory of profit, and the price system does not play the particular role that it has in the analysis of Marx and Kalecki, namely that of determining the distribution of profits among capitalists or firms (Lopez and Assous 2010, p. 197). The attempts in recent years to remedy this lacuna with theories of profit, based on mark-up pricing and empirical data on 
This is the version of the article accepted for publication in Review of Keynesian Economics, Vol. 5 (4), 576-585 published by Edward Elgar: http://dx.doi.org/10.4337/roke.2017.04.07

Accepted version downloaded from SOAS Research Online: http://eprints.soas.ac.uk/24792/

aggregate profit or wage shares, mimic the Ricardianism of latter-day fundamentalist

Marxists, in which finance does not affect the analysis beyond usury due to debt

accumulation.

The high profile of finance in recent years, due to its extravagance before 2008, and its apparent failure since that year, has highlighted the inadequacy of theories that see the economy as either a set of household exchanges, or a set of sectoral flows of funds, or merely a theory of value and production, with an accompanying state operating monetary and fiscal policy. Theories of financialisation have been advanced to incorporate the large amount of debt transactions into theories of household exchanges, or sectoral flows, or theories of value and production (e.g., Duménil, and Lévy 2011, Lapavitsas 2013). However, the significant achievement of these theories amounts largely to the incorporation of debt into basic, largely non-monetary, theories of production and distribution, muddled by accounting confusions and weak understanding of the operations of capital markets. (The argument is further extended in Toporowski 2012; Kregel 2010). This is apparent in the general drift of their policy conclusions which are towards monetary and financial regulation that will reduce credit to saving, reinstating 'classic' (i.e., early nineteenth century) capitalism unburdened by 'speculative' long-term finance, with its earlier problem of underconsumption and unemployment overcome by enlightened old-Keynesian fiscal policies (Duménil, and Lévy 2013; Phillips 2014).

\section{Conclusion}

This papers aims at a modest (but not total) de-monetisation of Keynesianism and Marxism, and the financialisation of economic theory, including Post-Keynesianism and Marxism. It does this by locating the Keynes's fundamental innovation in monetary theory in a capitalist 
This is the version of the article accepted for publication in Review of Keynesian Economics, Vol. 5 (4), 576-585 published by Edward Elgar: http://dx.doi.org/10.4337/roke.2017.04.07

Accepted version downloaded from SOAS Research Online: http://eprints.soas.ac.uk/24792/

system of production in which long-term finance distinguishes corporate capitalism from the 'classic' nineteenth-century capitalism described in Marx's Capital. This long-term finance is the condition for Keynes's theory of monetary circulation. Such finance is also the link with corporate finance and the theory of capitalist dynamics developed by Kalecki, Steindl and Minsky. It is not, as argued over by Post-Keynesians, neo-classicals, and Marxists, what money does for the exchange of commodities; nor even what money does for capitalist production; but what money does for finance that is the key to understanding the circulation of money in modern capitalism.

\section{Acknowledgement}

I am grateful to John Weeks, Riccardo Bellofiore, Joseph Halevi, the editors of this journal and anonymous referees for illuminating my understanding of the authors whose work is summarised in this paper. Their generosity leaves me with responsibility for any remaining errors and the manner in which I have reconstituted the history of economic thought around those authors.

\section{References}

Bellofiore, R. (2014) 'Luxemburg and Kalecki: The Actuality of Tadeusz Kowalik's Reading of the Accumulation of Capital' in R. Bellofiore, E. Karwowski and J. Toporowski (eds.) The Legacy of Rosa Luxemburg, Oskar Lange and Michat Kalecki Volume 1 of Essays in Honour of Tadeusz Kowalik Basingstoke: Palgrave. 
This is the version of the article accepted for publication in Review of Keynesian Economics, Vol. 5 (4), 576-585 published by Edward Elgar: http://dx.doi.org/10.4337/roke.2017.04.07

Accepted version downloaded from SOAS Research Online: http://eprints.soas.ac.uk/24792/

Borio, C. and Disyatat, P. (2015) 'Capital flows and the current account: Taking finance (more) seriously’ BIS Working Papers No. 525, Basle: Bank for International Settlements.

Chick, V. (1983) Macroeconomics after Keynes A Reconsideration of the General Theory Cambridge Mass.: The MIT Press.

Davidson, P. (1978) Money and the Real World London: Macmillan.

Diamond, D.W. and Dybvig, P.H. (1983) 'Bank Runs, Deposit Insurance, and Liquidity' Journal of Political Economy Vol. 91, No. 3, June, pp. 401-419.

Dobb, M. (1967) Papers on Capitalism, Development and Planning London: Routledge and Kegan Paul.

Duménil, G. and D. Lévy (1999), "Being Keynesian in the Short Term and Classical in the Long Term: The Traverse to Classical Long-Term Equilibrium”, The Manchester School, 67(6), pp. 648-716. 
This is the version of the article accepted for publication in Review of Keynesian Economics, Vol. 5 (4), 576-585 published by Edward Elgar: http://dx.doi.org/10.4337/roke.2017.04.07

Accepted version downloaded from SOAS Research Online: http://eprints.soas.ac.uk/24792/

Duménil, G., and Lévy, D. (2011) The Crisis of Neoliberalism Cambridge, Mass.: Harvard University Press

Halevi, J. (1992) ‘Kalecki and Modern Capitalism’ Monthly Review Vol. 44, No. 2, pp. 42-52.

Hawtrey, R.G., (1934) Currency and Credit London: Longmans Green and Co.

Hayek, F.A. (1932) 'A Note on the Development of the Doctrine of "Forced Saving"” Quarterly Journal of Economics Vo. 47, November, pp. 123-133.

Hilferding, R. (1981) Finance Capital a Study of the Latest Phase of Capitalist Development London: Routledge and Kegan Paul.

Hobson, J.A. (1924) Gold Prices and Wages An Examination of the Quantity Theory London: Methuen and Co.

Howard, M.C. and King, J.E. (1989) A History of Marxian Economics Volume I 1883-1929 Basingstoke: Macmillan.

Hyndman, H.M. (1932) Commercial Crises of the Nineteenth Century London: George Allen and Unwin. 
This is the version of the article accepted for publication in Review of Keynesian Economics, Vol. 5 (4), 576-585 published by Edward Elgar: http://dx.doi.org/10.4337/roke.2017.04.07

Accepted version downloaded from SOAS Research Online: http://eprints.soas.ac.uk/24792/

Kalecki, M. (1932) 'The Influence of Cartelization on the Business Cycle' in J. Osiatyński (ed.) Michat Kalecki Collected Works Volume I Capitalism Business Cycles and Full Employment Oxford: The Clarendon Press.

Kalecki, M. (1967) 'The Problem of Effective Demand with Tugan-Baranovsky and rosa Luxemburg' in J. Osiatyński (ed.) Michał Kalecki Collected Works Volume II Capitalism: Economic Dynamics Oxford: The Clarendon Press.

Keynes, J.M. (1930) A Treatise on Money London: Macmillan.

Keynes, J.M. (1936) The General Theory of Employment, Interest and Money London: Macmillan.

Keynes, J.M. (1937) 'Alternative Theories of the Rate of Interest' Economic Journal Vol. 47, June pp. 241-252.

Kindleberger, C.P., (1989) Manias, Panics and Crashes: A History of Financial Crises London: Macmillan.

Kindleberger, C.P. (1993) A Financial History of Western Europe New York: Oxford University Press.

Kiyotaki, N. and Moore, J. (1997) ‘Credit Cycles’ Journal of Political Economy Vol. 105, No. 2, April, pp. 211-248. 
This is the version of the article accepted for publication in Review of Keynesian Economics, Vol. 5 (4), 576-585 published by Edward Elgar: http://dx.doi.org/10.4337/roke.2017.04.07

Accepted version downloaded from SOAS Research Online: http://eprints.soas.ac.uk/24792/

Kowalik, T. (1959) O Ludwiku Krzywickim Studium społeczno-ekonomiczne Warszawa:

Państwowe Wydawnictwo Ekonomiczne.

Kowalik, T., (2014) Rosa Luxemburg Theory of Accumulation and Imperialism Basingstoke: Palgrave.

Kregel, J.A., (2010) ‘No Going Back: Why We Cannot Restore Glass-Steagall’s Segregation of Banking and Finance' Public Policy Brief No. 107, New York: Levy Economics Institute of Bard College.

Lapavitsas, C. (2013) Profiting without Producing: How Finance Exploits us All London: Verso Books.

Lawlor, M.S. (1994) 'On the Historical Origin of Keynes's Financial Market Views' in N. De Marchi and Mary S. Morgan (eds.) Higgling, Transactors and Their Markets in the History of Economics Annual Supplement to volume 26 History of Political Economy Durham and London: Buke University Press.

Lederer, E. (1925) 'Konjunktur und Krisen’ in Grundriss der Sozialőkonomik Tubingen: JCB Mohr, pp. 354-413.

López, J., and Assous, M., (2010) Michat Kalecki Basingstoke: Palgrave. 
This is the version of the article accepted for publication in Review of Keynesian Economics, Vol. 5 (4), 576-585 published by Edward Elgar: http://dx.doi.org/10.4337/roke.2017.04.07

Accepted version downloaded from SOAS Research Online: http://eprints.soas.ac.uk/24792/

Magdoff, H. and Sweezy, P.M. (1987) Stagnation and the Financial Explosion New York:

Monthly Review Press.

Marx, K.H. (1974a) Capital A Critique of Political Economy Volume II The Process of

Circulation of Capital London: Lawrence and Wishart.

Marx, K.H. (1974b) Capital A Critique of Political Economy Volume III The Process of Capitalist Production as a Whole London: Lawrence and Wishart.

Minsky, H.P., (1986) Stabilizing an Unstable Economy New Haven: Yale University Press.

Niebyl, K.H. (1946) Studies in the Classical Theories of Money New York: Columbia University Press.

Palley, T.I. (2010) “America's exhausted paradigm: macroeconomic causes of the financial crisis and great recession," New America Foundation, Washington, DC.

Phillips, T. (ed.) (2014) Europe on the Brink, Debt, Crisis and Dissent in the European Periphery London: Zed Books.

Reinhart, C.M. and Rogoff, K.S. (2008) This Time Is Different: Eight Centuries of Financial Folly Princeton N.J.: Princeton University Press.

Robertson, D.H. (1940) Essays in Monetary Theory London: P.S. King and Son. 
This is the version of the article accepted for publication in Review of Keynesian Economics, Vol. 5 (4), 576-585 published by Edward Elgar: http://dx.doi.org/10.4337/roke.2017.04.07

Accepted version downloaded from SOAS Research Online: http://eprints.soas.ac.uk/24792/

Shabani, M. and Toporowski, J. (2015) ‘A Nobel Prize for the Empirical Analysis of Assets

Prices’ Review of Political Economy Vol. 27, No. 1, January, pp. 62-85.

Steindl, J. (1945) Small and Big Business Economic Problems of the Size of Firms Oxford:

Basil Blackwell.

Steindl, J. (1952) Maturity and Stagnation in American Capitalism Oxford: Basil Blackwell.

Toporowski, J., (2005) Theories of Financial Disturbance An Examination of Critical

Theories of Finance from Adam smith to the Present Day Cheltenham: Edward Elgar.

Toporowski, J. (2012) 'Neologism as Theoretical Innovation in Economics: The case of "Financialisation"' Working Papers No. 171, Department of Economics, The School of Oriental and African Studies, University of London, March.

Toporowski, J., (2016) 'Kalecki and Steindl in the Transition to Monopoly Capital' Monthly Review July-August 2016 Vol. 68, No. 3, pp. 39-48.

Tugan-Baranovsky, M.I. (1923) Pyeryodycheskye promyshlennye krizisy. Istoriya anglyskikh krizisov. Obshchaya teoria krizisov Smolensk

Veblen, T. (1904) Theory of Business Enterprise New York: Charles Scribner's Sons. 
This is the version of the article accepted for publication in Review of Keynesian Economics, Vol. 5 (4), 576-585 published by Edward Elgar: http://dx.doi.org/10.4337/roke.2017.04.07

Accepted version downloaded from SOAS Research Online: http://eprints.soas.ac.uk/24792/

Withers, H. (1917) 'Lombard Street To-day’ in W. Bagehot Lombard Street A Description of the Money Market London: John Murray 1917.

Woodford, M. (2003) Interest and Prices, Foundations of a Theory of Monetary Policy Princeton NJ: Princeton University Press 